\title{
Perceptions of mobile network operators regarding the cost drivers of the South African mobile phone industry
}

\begin{tabular}{|c|c|}
\hline \multicolumn{2}{|c|}{$\begin{array}{l}\text { Authors: } \\
\text { Musenga F. Mpwanya }^{1} \\
\text { Cornelius H. (Neels) van } \\
\text { Heerden }^{2}\end{array}$} \\
\hline \multicolumn{2}{|c|}{$\begin{array}{l}\text { Affiliations: } \\
{ }^{1} \text { Department of Marketing, } \\
\text { Logistics and Sport } \\
\text { Management, Tshwane } \\
\text { University of Technology, } \\
\text { South Africa }\end{array}$} \\
\hline \multicolumn{2}{|c|}{$\begin{array}{l}{ }^{2} \text { Faculty of Management } \\
\text { Sciences, Tshwane University } \\
\text { of Technology, South Africa }\end{array}$} \\
\hline \multicolumn{2}{|c|}{$\begin{array}{l}\text { Corresponding author: } \\
\text { Musenga Mpwanya, } \\
\text { mpwanyamf@tut.ac.za }\end{array}$} \\
\hline \multicolumn{2}{|c|}{$\begin{array}{l}\text { Received: } 25 \text { Apr. } 2016 \\
\text { Accepted: } 21 \text { Aug. } 2016 \\
\text { Published: } 30 \text { Nov. } 2016\end{array}$} \\
\hline \multicolumn{2}{|c|}{$\begin{array}{l}\text { How to cite this article: } \\
\text { Mpwanya, M.F. \& Van } \\
\text { Heerden, C.H., 2016, } \\
\text { 'Perceptions of mobile } \\
\text { network operators regarding } \\
\text { the cost drivers of the South } \\
\text { African mobile phone } \\
\text { industry', Acta Commercii } \\
\text { 16(1), a398. http://dx.doi. } \\
\text { org/10.4102/ac.v16i1.398 }\end{array}$} \\
\hline \multicolumn{2}{|c|}{$\begin{array}{l}\text { Copyright: } \\
\text { (c) 2016. The Authors. } \\
\text { Licensee: AOSIS. This wo } \\
\text { is licensed under the } \\
\text { Creative Commons } \\
\text { Attribution License. }\end{array}$} \\
\hline \multicolumn{2}{|c|}{ Read online: } \\
\hline 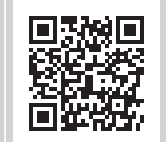 & $\begin{array}{l}\text { Scan this QR } \\
\text { code with your } \\
\text { smart phone or } \\
\text { mobile device } \\
\text { to read online. }\end{array}$ \\
\hline
\end{tabular}

Purpose: This study seeks to understand the perceptions of mobile network operators (MNOs) regarding the cost drivers of the South African mobile phone industry from a supply chain (SC) perspective. It also seeks to explore the possible cost interrelationships in the South African mobile phone SC.

Research design and methodology: A qualitative case study, involving six willing managers of MNOs, and by using semi-structured interviews, observation and documents, was conducted.

Findings: This study suggests that network infrastructure and network maintenance, handsets, logistics, technology, marketing and sales, training and consulting are the cost drivers in the South African mobile phone SC. These cost drivers are interrelated; and they influence one another in the mobile phone SC.

Implications: The findings of this study should assist MNOs in their monitoring of cost drivers and in the identification of cost reduction opportunities, in order to remain effective and efficient in the industry. This study's findings should help regulating authorities (such as the Department of Communications and the Independent Communication Authority of South Africa [ICASA]) to gain insights into the cost drivers of the South African mobile phone industry from the perspective of a network operator, and thus to develop appropriate mobile phone policies.

\section{Introduction}

Companies perform a variety of activities at each stage of the supply chain (SC), in order to ensure the smooth provision of products and services to their customers. These activities engender costs that inform the price paid by customers, and one of the ways to fully and effectively understand SC activities is through the identification and management of cost drivers. In this study, an SC is viewed as a network of independently co-ordinated business entities that join resources and efforts, in the form of a partnership, to provide products and services to their final customers.

Mpwanya and Van Heerden (2015:4) argue that SC partners who understand cost behaviour and put in place an adequate cost driver monitoring mechanism are more likely to achieve SC efficiency in the mobile phone industry. Mowen, Hansen and Heitger (2014:293) define a cost driver as a causal factor that measures the output of the activity that leads to (or causes) changes in costs. Cokins and Căpuşneanu (2010:8) view a cost driver as: 'the factor, which generates [the] occurrence of the consumption of resource (capacity) expenses'. According to Maher, Stickney and Weil (2012:79), a cost driver measures the activity that causes costs to occur. The business literature, particularly the cost model literature, provides evidence of the association and relation between the concept of a cost driver and that of the activity-based costing (ABC; Amdee et al. 2014:719; Cokins \& Căpuşneanu 2010:9; Mpwanya \& Van Heerden 2015:4). This view and understanding is expressed by Cokins and Căpuşneanu (2010:9), who state that 'the most significant cost driver's definition applies to the activity-based costing (ABC) method'.

Popesko (2010:103) points out that the ABC method was primarily designed to solve the challenges of traditional cost-accounting systems. Gujral et al. (2010:69) assert that traditional cost-accounting systems fail to reflect the share of indirect costs to the individual services. These authors go on to indicate that the traditional cost-accounting systems combine all the indirect costs, also known as overhead costs, and assign them to the various services, according to the share of service volume or direct costs. According to Beekman (2007:39), ABC is a dual approach that generally begins 
with attributing direct and indirect costs to business processes. These are then finally assigned to business objects (products, customers or distribution channels).

\section{Lin (2012:13) points out that the ABC methodology is:}

'generally used as a tool for understanding product and customer costs, as well as profitability, based on the production or performing processes. As such, $\mathrm{ABC}$ has largely been used to support the strategic decisions, such as pricing, outsourcing, and the identification and measurement of process improvement initiatives.'

Tsai et al. (2012:102), in their study on environmental protection, show that the $\mathrm{ABC}$ method when compared with the traditional cost-accounting system can be used to identify the environmental costs of different pollutants hidden in the overheads, and to estimate the environmental costs of a finished product more precisely.

Many studies show that capital expenditure (Capex) is one of the major cost drivers of the mobile phone industry (Geoffron 2007:37; Harmantzis \& Tanguturi 2007:108; Sabat 2002:53). Pattanavichai, Jongsawat and Premchaiswadi (2011:143) define Capex as the funds invested to acquire the physical assets, in order to upgrade the infrastructure. This comprises the site construction costs, the base station, switch costs, antenna costs, radio costs and the integration costs, which are paid for by building a single cell site. Comparing Capex with operating expenditure (Opex) in terms of figures, Al-Debei and Avison (2009:14) point out that Opex exceeds Capex. Mishra et al. (2005:3) view Opex as the cost expended to operate and maintain the network infrastructure, and to provide services to customers.

Capex has a significant impact on a mobile network operator (MNO)'s ability to generate a return - in the form of interest on an investment (Sabat 2002:53). An MNO is a firm that owns a mobile network facility and provides mobile telecommunication services to customers (Jing \& Xiong-Jian 2011:157). MNOs also offer location information, user identification and billing services to customers (Camponovo \& Pigneur 2003:7). In relation to the provision of products and services in the value chain, Cricelli, Grimaldi and Ghiron (2011:23) assert that MNOs offer their products and services at various levels of the value chain, including the network infrastructure (network equipment, spectrum and operations), the mobile service upgrade and supply (tariffing, billing and network services and products), as well as the interface to their final consumers (distribution, marketing and customer care). In South Africa, there are four MNOs, which include Cell C, MTN, Vodacom and 8.ta (Lange 2012). These MNOs are involved in a number of business activities including network connectivity, starter packs and air times. This makes them stronger than other players in the industry (Mpwanya \& Van Heerden 2015:2).

Globally, the mobile telecommunications industry has seen a rapid growth, and it had recorded over 3.6 billion new mobile subscriptions at the end of 2014 (GSMA 2015:6). This industry growth is mainly attributed to the adoption of new technologies and the speed of technological change (MTN Group Report 2014:4; Telkom Annual Report 2015:24), which resulted in changes in the mobile consumption patterns, particularly for data-seeking consumers. However, there has been an increase in Capex due to the upgrade of network capabilities, in order to meet the demand for mobile telecommunication services from customers (Ernest \&Young 2015:7). While the prices of mobile telecommunication services are falling (International Telecommunication Union 2015), South Africa's telecommunication market is criticised for having high mobile telecommunication costs for the final customers or end users (Mpwanya \& Van Heerden 2015:3; Research ICT Africa 2012:1).

Despite the exponential growth of the telecommunication industry globally, and the ever-growing need for lower mobile phone costs, no available study has yet examined the cost drivers in the South African mobile phone industry. The research question posed for this study is: What are the cost drivers of the South African mobile phone SC?

The purpose of this study was to understand the perceptions of network operators regarding the cost drivers of the South African mobile phone industry from an SC perspective, and to explore the possible cost interrelationships in the South African mobile phone SC. The remaining sections of the paper provide a review of the literature on the mobile phone industry and on cost drivers and SC costing. This is followed by the research methodology to answer the research question. This is then followed by the study's findings and the conclusion with its implications.

\section{The literature review} The mobile phone industry

Mobile telecommunications is a capital-intensive industry in nature (Gunasekara 2015:333; Telkom Integrated Report 2015:58). In a rapidly changing business world, featured by new technologies at an ever-faster rate, technology is seen as the single biggest driver of skills shortage in the world (H.R. Future 2009). This is aggravated in the telecommunication and information technology sectors, which are regarded as the backbones and drivers of the economic growth of countries (H.R. Future 2009). Because of technology convergence and the speed of technological change, South Africa's MNOs have upgraded their network infrastructural capabilities to respond to prompt and the high demand for data volume. This has paved the way for the introduction of the highly advanced mobile technology, long-term evolution (LTE), commonly known as Fourth-Generation (4G) technology. However, the 4G technology operates alongside ThirdGeneration (3G) and Second-Generation (2G) technologies, in order to cater for the needs of various income groups in the country. This is consistent with the findings of Golde, Redon and Seifert (2013:33). These authors point out that the $2 \mathrm{G}$ devices will not disappear soon, but they will rather complement $3 \mathrm{G}$ and $4 \mathrm{G}$ devices on the market. 
It should be noted that the $2 \mathrm{G}$ network offers digitalised voice, short message services and multimedia messages (Jain, Rajput \& Dixit 2015:88). According to Alexoiu et al. (2010:671), the $3 G$ network is an advanced enabling technology for handsets that require high-speed data access and real-time multimedia traffic.

In a telecommunication sector survey, it was found that there is an insufficient pool of qualified candidates entering the telecommunication industry. Therefore, the industry players organise in-house training (H.R Future 2009). Burmeister, Landelahni Amrop CEO, echoes the criticality of skills shortage in the telecommunication industry, and he points out that the shortage of key skills constitutes a major socioeconomic developmental challenge for South Africa, as the telecommunication industry plays a critical role in fostering development (Dlamini 2012). To overcome this challenge, the industry needs a long-term substantial investment in skills development and skills security.

In the quest to meet customers' requirements for on-time and quality products and services, many companies, both in the manufacturing and the service sector, tend to provide a bundle of products and services. For instance, mobile telecommunication companies, although being part of the service sector, integrate handsets and starter packs (products) into their core offering, network connectivity (service).

In order to encourage network accessibility and to increase mobile penetration, many countries, including South Africa, subsidise handsets. By subsidising handsets, MNOs expect a profit from the airtime sales. Dedrick, Kraemer and Linden (2011:514) point out that in mobile phone markets, in which handsets are not subsidised, handset unit sales are low, because of the high purchasing costs, resulting in low total profits and a negative impact on some SC players, particularly MNOs, handset manufacturers and component suppliers. According to Frisanco (2010:772), handset subsidies approximately account for only $4 \%$ of the Opex of an MNO. Van Eeden (2009:4) indicates that the contribution of handsets, subscriber identity modules (SIMs) and vouchers accounts for $19.7 \%$ of the expenditure composition of MTN SA (a major MNO in the South African industry). This shows the importance of handsets, SIMs and vouchers (airtimes) in enabling and ensuring end users' connectivity. The connection cost comprises the handset delivery cost, the cost of starter packs and the cost of the contract.

To ensure the continuous availability of mobile services to customers, a reliable network infrastructure is critical. According to Wyman (2007:1), costs associated with procuring network infrastructure amount to approximately $60 \%-80 \%$ of the total investment for an MNO. Network operations account for between $15 \%$ and $26.4 \%$ of the Opex (MTN Group Report 2014). Network management amounts to $13 \%$ of the typical cost structure for an integrated MNO (Anderson \& William 2004:52).
In order to gain customers and to develop brand loyalty, marketing efforts are needed. According to Anderson and William (2004:52), marketing and sales costs account for $21 \%$ of the typical costs for an integrated MNO. The MTN Annual Report (2014) shows that selling, distribution and marketing costs are the second largest costs, and they represent $19 \%$ of total expenditure.

Katz and Hamilton (2003:32) assert that one of the global, prominent features of the telecommunication industry is the high investment in Opex. Information technology, finance and sales and marketing are major contributors to the overall cost. Several studies show that high investment in the form of Capex does not automatically lead to high returns on investment in the telecommunications industry globally (Firli, Primiana \& Kaltum 2015:135; PWC Analysis 2012:3). This low return on investment has become a challenge that the industry faces (Firli et al. 2015:135). Arguably, Gunasekara (2015:333) states that 'without making sustainable returns on investments, MNOs would not be able to continue to invest in technology development'. In an effort to manage the challenge of low returns on investment faced by the mobile telecommunication industry, while acknowledging the capital-intensive nature of the mobile telecommunication industry, it is advised that striking a balance between the adoption of new technologies and the required return on investment is crucial (Telkom Integrated Report 2015:58).

Although Capex and Opex are critical factors in ensuring the provision of products (handsets and network-related equipment) and those services, which generate income for mobile phone companies and for fulfilling their obligations to shareholders, it is important that these costs be managed effectively along the SC. Therefore, an appropriate SC costing approach is required.

\section{Cost drivers and supply chain costing}

To achieve their organisational goals, both manufacturing companies and service companies perform a series of transactional activities that generate costs. Understanding and managing cost drivers is critical in ensuring the effectiveness and efficiency of any company, SC or industry. Miller (1992:44) argues that identifying and implementing adequate cost drivers position an organisation that seeks to gain insights into the nature and the factors that contribute to the relationships between cost drivers and the total overhead costs of an operation. Considering the oligopolistic nature and the high operating costs in the South African mobile phone industry, Mpwanya and Van Heerden (2015:6) advocate the use of cost driver analysis, as a way of enhancing value-adding activities and processes, as well as the relationships among mobile phone companies.

Traditional costing tools, specifically designed to analyse production costs, are unable to capture the processes that take place in the SC. The inability to capture processes across 
the SC has led to the emergence of a number of costing models, including $\mathrm{ABC}$, designed to attribute costs to activities, and being measured by cost drivers, as well as the costs to serve (CTS), developed to assess customer costs and the total cost of ownership (TCO), designed to link costs with the selected suppliers of products and services (Su \& Lei 2008:1627). The literature review on SC costing focuses on $\mathrm{ABC}$ because it is the only costing model that specifically deals with cost drivers, the focal issue of this study.

\section{Activity-based costing}

Given the capital-intensive nature of the telecommunication industry, finding innovative ways to improve operational processes and to control costs is critical. One of the possible ways to control costs in the telecommunication space and to provide mobile services at reduced rates is the use of the ABC system. Michalska and Szeweiczek (2007:92) claim that $\mathrm{ABC}$ focuses attention on the activities and processes. This implies that an enterprise purchases different supplies, then transforms these supplies into products (services) and delivers these to customers with an exchange of funds. Arguably, Rachchh and Rachchh (2015:252) maintain that ABC is built on the principle, according to which 'products consume activities; and activities consume resources'.

Amdee et al. (2014:719) state that 'ABC provides a means of costing the activities associated with a given product or service; and it allows overhead costs to be allocated to each activity taking place in the production process, or the provision of a service'. Rich et al. (2010:974) broaden the understanding of the $\mathrm{ABC}$ concept to align this with the changing business structure and requirements of the twentyfirst century. The alignment is done by managing both upstream and downstream activities, or by managing areas of the production, as well as determining the upstream costs of suppliers, and the downstream costs of customers.

According to Lin (2012:13), companies using the ABC methodology aim to assign costs more accurately and to improve inefficiency. This author further states that the ABC methodology is seemingly the preferred approach used to support strategic business decisions relative to pricing, outsourcing and the identification and measurement of process engineering efforts (Lin 2012:13). Several authors are of the opinion that the $\mathrm{ABC}$ method basically allocates the costs to operations through individual activities, and it measures these activities by cost drivers (Cokins \& Căpuşneanu 2010:11; Needles, Powers \& Crosson 2011:951).

In the $\mathrm{ABC}$ method, the costs are determined for each activity performed, and the specific cost drivers are identified for the cost object (such as products, services and customers). The data collection is conducted, based on the effect of each cost issue (object) on the activity in question (Agndal \& Nilsson 2007:224). Park and Simpson (2008:102) contend that ABC can help companies that produce a wide range of products, to achieve effectiveness by identifying complex production activities with certainty and by measuring their cost drivers accurately.
However, Cokins and Căpuşneanu (2010:11) caution managers of companies (decision-makers) against making incorrect choices of cost drivers, as these could lead to misallocation of costs upon cost objects and ultimately inaccurate and erroneous costs that do not reflect reality. Arguably, Fiorentino (2014:1438) points out that flawed estimates in indirect costs can negate the accuracy and reliability of the ABC system, making it unreal, where the final cost is made up largely of the direct costs.

The traditional cost-accounting system uses a single cost driver, such as direct labour, or output volume to assign the indirect costs. This systematically distorts product costs in the modern manufacturing landscapes, in which indirect costs contribute to production costs significantly (Wang et al. 2010:367). Krug et al. (2009:236) indicate that the strength of $\mathrm{ABC}$ lies in the use of a multiplicity of cost drivers, thereby illustrating the relationship between resource costs and activities, as well as that between activities and products. Cokins and Căpuşneanu (2010:15) provide the most important benefits associated with the application of cost drivers, which include the improvement of a company's performance, the improvement of employee and manager awareness, the periodic review of costs, costs control with better computations, the elimination of costs for non-valued activities and the actualisation of costs to individual products.

Amdee et al. (2014:719) believe that the use of more multiple cost drivers is important for companies that seek to increase activities' accuracy through the ABC system. Vincenti-Brown (2006:329) argues that the emphasis of ABC on crossfunctional processes is the reason for its important application in a single company, and the ABC system's potential increases, when applied to SCs. He continues to argue that in the SC setting, any company's operations are part of a flow from incoming (or upstream) partners to outgoing (downstream) partners. Linking the application of $\mathrm{ABC}$ to supplier-customer costs, Rich et al. (2010:974) outline the fact that $\mathrm{ABC}$, in particular, is often used to more accurately determine the upstream costs of suppliers, and the downstream costs of customers.

Although the concept of $\mathrm{ABC}$ was primarily coined for the manufacturing environment, the concept is being used in the service sector, because of the growing need for accurate cost estimates by service companies globally. Reeve, Warren and Duchac (2009:458) argue that service companies need to determine the costs of their services, in order to make decisions on pricing, promotional and other activities. They continue to argue that the use of single- and multipledepartment, overhead rate methods could well lead to service cost distortions similar to those in manufacturing firms because of inaccurate and improper service-cost assignment (Reeve et al. 2009:458).

Thus, many service companies use $\mathrm{ABC}$ for determining the cost of services more accurately. Using the $A B C$ approach to identify cost drivers in the service sector, such as telecommunication in a developing economy context 
(South Africa), appears to be an interesting endeavour, and it should provide insights into those activities that drive costs SC-wide and a mechanism to manage these activities more effectively.

\section{The research methodology The overall research approach and the participants}

This study has followed a qualitative research approach by using the single-case design to understand the cost drivers in the South African mobile phone SC. There seems to be confusion over the use of the term 'case study' - in both academic and practitioner circles. Nieuwenhuis (2007:75) outlines the fact that the term 'case study' can be used for a unit of analysis (for instance, in the case of a particular organisation), or for a research method. For the purpose of this study, this dual usage or understanding is applicable.

The participants were managers of MNOs responsible for logistics, or procurement, or SC. They were selected because of their knowledge of the mobile phone SC and their willingness to participate in the study. The sampling method used to select the participants was purposeful. Prior to the commencement of interviews, the study was piloted by two willing managers of MNOs, in order to refine the interview protocol, and to ensure the clarity in the questions to be asked and of the procedures to be followed (Yin 2009:92). Convenience, access and geographical proximity were the main criteria used for selecting the participants in the pilot case study (Yin 2009:93).

\section{The data collection}

Semi-structured interviews, consisting of open-ended questions, were conducted with six managers from three MNOs (two managers per MNO, but operating in different branches, in order to obtain a variety of opinions), as one MNO declined to participate in this study. These interviews were conducted from August 2011 to December 2011. Because of the changing nature of the mobile phone industry, followup interviews were conducted from June 2016 to August 2016. The participants in follow-up interviews were the four managers of MNOs who participated in the initial interviews, and two new managers of MNOs, who replaced the two managers who had previously participated in the interviews. Both the initial interviews and the follow-up interviews were all pre-arranged, and they lasted for an average of 1 hour and 20 minutes. Saturation was reached at interview number six, as the same responses were being received from the managers of MNOs.

\section{Validity, reliability and triangulation}

All the interviews were audio-recorded and transferred from the audio-recording device onto the desktop after each interview session. They were then labelled, listened to from Windows Media Player and finally securely stored. The interview transcripts were verbatim and validated by the managers of MNOs. To ensure that the true meaning was obtained from the participants' responses, the reflection technique was used. This technique consists of asking the participants to confirm their opinions through a restatement, or asking the participants to respond to the accuracy of their statements or opinions after the researcher had restated those (Baxter \& Jack 2008:556). In addition, probing by using the 'what' and 'how' questions was used to address the issues associated with validity and reliability in qualitative studies, as suggested by McKinnon (1988:52).

The probing enabled the authors to refrain from making their own assumptions from responses received from the participants, but they provided an opportunity for the participants to voice their opinions clearly and to reduce the authors' own bias to a minimum (McKinnon 1988:52). The coding and the themes arising from the interview data were confirmed by the co-author to ensure correctness. Data triangulation was achieved in this study, as the opinions from different managers of MNOs were compared and contrasted. In addition, method triangulation was used because multiple sources of evidence, including interviews, observations and annual reports of MNOs and other published documents on telecommunication costs, were used and compared.

\section{The data analysis}

Interview transcripts were analysed with the help of Atlas. ti - using a three-phased process, as proposed by O'Dwyer (2004). This is an adaptation of the process of Miles and Huberman (1994). This includes data reduction, data display and data interpretation, as well as conclusion drawing. In the data reduction phase, the interview data for each manager of MNO were transferred from the voice recorder to the desktop and labelled for confidentiality reasons. The interview data for each manager of MNO were carefully listened to via the desktop Windows Media Player and reviewed, and this led to the preliminary themes, which were noted and refined at a later stage. In addition, all the transcripts were transferred to Atlas.ti (version 6.2) and coded - using a bottom-up approach, as this study was inductive. As one transcript was compared with another, in order to build patterns and themes, various similarities and contrasts were identified.

In the data display phase, the linkages resulting from the data reduction phase were identified through mind mapping. This enabled the authors to link this study with the only available study on cost drivers (by Moroney \& Kual 2003). The study by Moroney and Kual (2003:2) indicates that it is impossible to consider individual cost drivers in isolation, because of the multiple factors that influence each component of the healthcare delivery system, and a shift in one cost driver has an effect on another. The themes resulting from the data reduction process reflected on this study's research question. The matrices were made by using core codes, which assisted in comparing the responses of the different managers of MNOs, and to identify the patterns thereof for refinement at the data interpretation and conclusion drawing stages. To draw and verify the conclusions, this study investigated the 
opinions of the managers of MNOs, across and within the matrix, to build a more comprehensive view on cost drivers in the South African mobile phone SC. All stand-alone quotations were noted. On the other hand, thick descriptions, as voiced by the managers of $\mathrm{MNO}$, together with pertinent quotations, were selected as signals and indicators of how managers of MNOs understand cost drivers in the mobile phone SC.

According to Richards (2009:57), a 'thick description' contains a detailed account of recall and imagery, as well as an interpretive comment made in a specific context, where appropriate. Arguably, Lincoln and Guba (1985:316) state that a thick description provides others with a literature base for further investigations in terms of the transferability of findings to other environments. As opposed to quantitative research that seeks statistical generalisation, this qualitative case study has endeavoured to develop an analytical generalisation because people are given the opportunity either to learn from the case for themselves, or to apply to a population of cases (Creswell 2007:163).

\section{The findings}

This section reports on the findings, according to the research question, and the themes that emerged from the data analysis are here discussed in relation to the available literature. To protect the identities of the managers of MNOs, pseudonyms were used, and the names of the companies for which they work were withheld. To answer the research question, 'What are the cost drivers and their influence or interrelationships in the South African mobile phone SC?', the participants were asked the following interview questions:

- From the cost structure of the South African mobile phone $\mathrm{SC}$, can you please mention the major expenditures?

- Do you think that costs in the mobile phone SC influence one another?

- * If yes, please elaborate.

- * If no, please elaborate.

\section{The perceptions on the major cost components in the South African mobile phone industry}

With regard to the first question concerning the major cost components in the South African mobile phone industry based on the cost structure, six themes emerged. These include: network infrastructure and network maintenance, handsets and other accessories, logistics, technology, marketing and sales, and training and consulting.

\section{Network infrastructure and network maintenance}

Network infrastructure and network maintenance emerged as two of the major cost components in the South African mobile phone industry. This is listed, along with other major cost components, as is shown in the following quotation from one of the participants:

\begin{abstract}
'...the major expenditures are network infrastructure and maintenance of the network infrastructure, marketing and sales, technology and headcount.' (Keziah: MNO, General Manager Procurement, 47-year-old male)
\end{abstract}

Network infrastructure is one of the key resources in the portfolio of MNOs. It enables network operation and the provision of voice and data services to customers. This study shows that network infrastructural building and network infrastructural maintenance are among the cost drivers of the South African mobile phone SC. This finding is in agreement with the previous studies that show that network operations account for about $15 \%-20 \%$ of the Opex, as compared to network management that amounts to $13 \%$ of the typical cost structure for an integrated MNO. Network infrastructural procurement costs amount to approximately $60 \%-80 \%$ of the total Capex for an MNO (Anderson \& William 2004:52; Frisanco 2010:772; Wyman 2007:1).

Building and maintaining a network infrastructure requires substantial costs in South Africa because most of the network building and maintenance equipment is imported. The technological changes in the mobile telecommunication space constrain mobile phone companies, and particularly MNOs, to continuously upgrade their network infrastructure, in order to cope with the increasing demand for data, along with voice.

\section{Handset acquisition}

This study found that the acquisition of handset and other accessories is one of the major cost components in the South African mobile phone industry, as shown in the following quotation from one of the participants:

\footnotetext{
'... the major costs that influence the price of mobile telecommunication services include devices acquisition and the related costs, including handset accessories, distribution costs, security costs, insurance, warehousing costs.... In addition, labour costs are also high - not only in the area of telecommunication, but in other industries also.' (Ephraim: $\mathrm{MNO}$, Sourcing Manager, 50-year-old male)
}

One of the objectives of network infrastructure is to facilitate the smooth running of mobile handsets or devices. Handset acquisition and ownership drive the purchasing of a number of complementary products, including subscriber identity module (SIM) cards, also known as starter packs and airtime. The MTN Group Report (2014) shows that the cost of handsets and other accessories amounts to $14.6 \%$ of the total Opex.

In South Africa, MNOs are involved in the handset, starter packs and airtime businesses. This makes South Africa a unique mobile phone market, compared with most of the mobile phone markets in the rest of the world - where MNOs deal with the airtime business only. On the other hand, this situation has made South Africa's MNOs powerful and dominant. MNOs purchase handsets from device manufacturers locally, or internationally, depending on 
whether these device manufacturers havelocal representatives or not. Device manufacturers are not allowed to sell handsets to retailers, dealers or end users directly - without the listing of handsets by MNOs or service providers.

One of the factors that affect handset acquisition costs when purchasing devices from device manufacturers overseas is the rate of exchange. Although MNOs conform to the principle of economy-of-scale in procuring handsets, the handset acquisition cost in South Africa is high, because of the sourcing process and the increasing mobile telecommunication demand by low-, middle- and highincome groups. In South Africa's business model, MNOs focus on starter packs, rather than on handsets, because handsets are just a means to connect with the network. MNOs spend considerable funds in handset subsidies, to ensure that the end users of various income groups can purchase handsets and connect with MNOs. This implies that MNOs drive the sale of handsets, in order to increase airtime sales. The profits generated from network connectivity assist MNOs to compensate for the handset subsidy and other operating costs, such as SC costs.

\section{Logistics}

Logistics is listed among the major cost components in the South African mobile phone industry, as shown in the following excerpt from one of the participants:

, ... the major costs that influence the price of mobile telecommunication services include device acquisition and the related costs, including distribution costs, security costs, insurance, warehousing costs. ... In addition, labour cost is also high, not only in the telecommunication industry, but also in other industries.' (Ephraim: MNO, Sourcing Manager, 50-yearold male)

In the mobile phone market, logistical costs comprise warehousing costs and transportation costs. No findings from any of the previous studies support this study's finding, because of its particularity. MNOs in South Africa warehouse a number of items, which include devices, SIM cards, mobile phone accessories, marketing materials, generators, air conditioners and other building materials used in the building of a network infrastructure. The warehousing and transport of these items to dealers and retailers requires tight security measures. High-risk items, such as mobile handsets, require insurance measures, and the cost associated with distributing handsets is high because it also includes security and insurance costs. Security measures are not only needed for handset warehousing and distribution, but they are also required for base stations (key resources in the provision of mobile services), stores and administrative buildings. These costs also contribute to the Opex of MNOs.

Most of the equipment needed in the building and maintenance of MNOs' network infrastructure is imported, and this leads to shipping and other transportation-related costs and duties that need to be covered. When it comes to the local logistical needs, some MNOs outsource their logistical services from third-party logistics companies, while others use other business models.

\section{Technology}

Technology has emerged as one of the major cost components in the South African mobile phone industry. This is shown in the following quotations from two of the participants:

\footnotetext{
' Technology is what drives the telecommunications industry, and it is one of the main expenditures of the telecommunication industry .... Technology is changing rapidly, and the race among different network operators is about ensuring the provision of mobile network services to customers.' (Andrew: MNO, Head of Logistics Department, 50-year-old male)

'... the major expenditures are network infrastructure and the maintenance of the network infrastructure, marketing and sales, technology and headcount.' (Keziah: MNO, General Manager Procurement, 47-year-old male)
}

This study's findings corroborate with the study by Katz and Hamilton (2003:32) that group information technology among the major components of the overall cost of the telecommunication industry's Opex. However, the International Telecommunication Union (2012:144) notes that the speed of technological change remains the key differentiator of telecommunications, compared with other infrastructural businesses globally. Therefore, MNOs have to continuously upgrade their network capacity, in order to meet the emerging mobile market demands because servicing end users with the latest working technology, at a profit, is the crux of what MNOs are facing in the world, particularly in South Africa.

It is believed that increased competition, deregulation and other factors are contributors to the high cost technological investment and the increased volatility in the telecommunication market (Harmantzis, Trigeorgis \& Tanguturi 2006:3). End users seek out the newly marketed handsets, because of the technology that drives these handsets. Considering the increasing competition, the high cost of technology and the rate of technological change in the mobile phone space, South African MNOs should strategically decide how to price these smart phones. At the same time, MNOs make large investments in upgrading their network infrastructures from the $2 \mathrm{G}$ network to the $4 \mathrm{G}$ network via the $3 G$ network, in order to respond to data usage requirements.

\section{Marketing and sales}

Marketing and sales are listed among the major cost components in the South African mobile phone industry, as shown in the following quotation from one of the participants:

\footnotetext{
'... the major expenditures are network infrastructure and the maintenance of the network infrastructure, marketing and sales, technology and headcount.' (Keziah: MNO, General Manager Procurement, 47-year-old male)
}

This study's findings corroborate with other studies, which mention that marketing and sales costs account for 
$19 \%$ - 21\% of the combined expenditure of an MNO (Anderson \& William 2004:52; Katz \& Hamilton 2003:32; MTN Group Report 2014). South Africa's mobile phone companies, particularly MNOs, make large investments in marketing and sales, and most of the MNOs outsource their marketing services from service providers. More often than not, marketing and sales efforts involve the advertising of handsets and other service propositions, including data bundles on television, on the printed and electronic media, and other social platforms on a daily basis.

The advertising costs of South Africa's MNOs have been on the rise since 2009, when the need for meeting the demands of various income groups in the country began to increase, and these costs may continue to be hiked, as new technologies and end users' needs increase. The ultimate goal of spending large amounts on marketing and sales is to entice end users to purchase airtime and data, and to use their network.

\section{Training and consulting}

This study found training and consulting to be two of the key cost components in the South African mobile phone industry, as shown in the following quotation from one of the participants:

'... the main costs in the telecommunication industry are skills costs (local and foreign expertise), network infrastructure equipment costs and software costs.' (Paul: MNO, Contract manager in the Procurement Department, 39-year-old male)

South Africa faces a skills shortage in the telecommunication industry (Dlamini, 2012; H.R. Future 2009). Because of the speed of technology change, and the skills needed to use the imported equipment in the building and upgrade of the network infrastructure in the South African telecommunication industry, mobile phone companies seek consulting services from foreign firms, and they use foreign expertise to train local technical personnel - either locally or overseas - in order to familiarise them with the imported equipment. The costs associated with the training of local personnel and consulting - to ensure continuous network operation and service provision - are extremely high.

\section{The perceptions on the cost influence or interrelationships in the mobile phone supply chain}

The findings of this study show that MNOs are of the opinion that cost drivers in the South African mobile phone SC are interrelated, and they influence one another because nothing in the SC happens in isolation. This insight is captured in the following quotes from two of the participants:

\footnotetext{
'... the cost of mobile phone devices influences the related cost, as they are all dependent on one another... This means that the cost of devices influences the cost of security, the cost of distribution and the warehousing cost. ... The higher the device prices, the higher the related costs.' (Ephraim: MNO, Sourcing Manager, 50-year-old male)
}

... all costs are related; because we look at the total cost of ownership, [in order] to have a comprehensive picture in terms of cost, and nothing is happening in isolation.' (Philetus: MNO, Senior Procurement Group Consultant, 50-year-old female)

This view is in agreement with those of the findings of Moroney and Kual (2003:2) that indicate the impossibility of considering individual cost drivers in isolation, because of the multiple factors that influence each component of the healthcare delivery system, and a variation in one cost driver has an inevitable effect on another.

Upgrading the network infrastructure from $2 \mathrm{G}$ technologies to $4 \mathrm{G}$ technologies influences SC costs in the mobile phone industry because MNOs control their costs from a TCO perspective. The cost of technology change affects the related costs, which include network equipment costs, handset costs and training and consulting costs, on the one hand, while on the other hand the cost of device acquisition influences the cost of insurance, warehousing, security and distribution. This means that the higher the device acquisition cost, the higher the related costs (insurance, warehousing, security and distribution).

\section{Conclusion and implications}

Mobile telecommunications is an infrastructure-based and technology-driven industry. Activities performed along the mobile phone SC are critical in the provision of mobile services to customers. In order to achieve their business goals, MNOs need to understand and to manage their costs properly, and to service end users at low costs, and at an acceptable profit level. This study, undertaken to understand the perceptions of managers regarding cost drivers, as well as cost influence from an SC perspective, suggests that network infrastructure and network maintenance, handsets, logistics, technology, marketing and sales, and training and consulting are the cost drivers in the South African mobile phone SC. These cost drivers are interrelated, and they influence one another in the South African mobile phone SC.

The findings of this study should assist MNOs in cost driver monitoring, and in the identification of cost reduction opportunities, in order to remain more efficient in the industry. The knowledge generated through this study should help regulating authorities (the Department of Communications and ICASA) to gain insights into the cost drivers of the South African mobile phone industry from the perspective of a network operator and to develop appropriate mobile phone policies.

\section{Acknowledgements Competing interests}

The authors declare that they have no financial or personal relationships which may have inappropriately influenced them in writing this article. 


\section{Authors' contributions}

The article is the outcome of a doctoral thesis presented and defended by M.F.M. at the Tshwane University of Technology under the supervision of C.H.V.H.

\section{References}

Agndal, H. \& Nilsson, U., 2007, 'Activity-based costing: Effects of long-term buyersupplier relationships', Qualitative Research in Accounting \& Management 4(3), 222-245. http://dx.doi.org/10.1108/11766090710826655

Al-Debei, M.M. \& Avison, D., 2009, Business model requirements and challenges in the mobile telecommunication sector, viewed 27 January 2011, from http://bura. brunel.ac.uk/handle/2438/380/

Alexoiu, A., Bouras, C., Kokkinos, V. \& Rekkas, E., 2010, 'An improved mechanism for multiple MBMS sessions assignment in B3G cellular networks', Wireless Network 169(3), 671-686. http://dx.doi.org/10.1007/s11276-009-0161-6

Amdee, N., Sonthipermpoon, K., Arunchai, T. \& Warawut, P., 2014, 'Optimal cost drivers in activity-based costing based on an artificial neural network', Proceedings of the 2014 IEEE, viewed 28 July 2016, from http://ieeexplore.ieee.org/stamp/ of the 2014 IEEE, viewed 28 ?arnumber $=7058732$

Anderson, J. \& William, B., 2004, 'Unbundling the mobile-value chain', Business Strategy Review 15, 51-57. http://dx.doi.org/10.1111/j.0955-6419.2004.00328.x

Baxter, P. \& Jack, S., 2008, 'Qualitative case-study methodology: Study design and implementation for novice researchers', The Qualitative Report 13(4), 544-559.

Beekman, G.J., 2007, 'Activity-based costing of IT', IEEE International Conference on Exploring Quantifiable IT yields, Amsterdam, The Netherlands, March 19-21.

Camponovo, G. \& Pigneur, Y., 2003, 'Business-model analysis applied to mobile business', 5th international conference on enterprise information systems,
Angier's, Maine-et-Loire, France, April 23-26, viewed 04 September 2012, from Angier's, Maine-et-Loire, France, April 23-26, viewed 04 Septemb
http://www.hec.unil.ch/gcampono/publications/GC2003ICEIS.pdf

Cokins, G. \& Căpușneanu, S., 2010, 'Cost drivers. Evolution and benefits', Theoretical and Applied Economics 8(549), 7-16.

Creswell, J.W., 2007, Qualitative inquiry and research design, Choosing among five approaches, 2 nd edn., Sage Publications, Thousand Oaks, CA.

Cricelli, L., Grimaldi, M. \& Ghiron, N.L., 2011, 'The competition among mobilenetwork operators in the telecommunication supply chain', International Journal of Production Economics 131(1), 22-29. http://dx.doi.org/10.1016/j.ijpe. 2010.02.003

Dedrick, J., Kraemer, K.L. \& Linden, G., 2011, 'The distribution of value in the mobile phone supply chain', Telecommunications Policy 35(6), 505-521. http://dx.doi. org/10.1016/j.telpol.2011.04.006

Dlamini, P., 2012, Telecoms skills shortage critical, viewed 23 October 2012, from http://www.sowetanlive.co.za/incoming/2012/03/27/telecoms-skills-shortagecritical

Ernest \& Young, 2015, Global telecommunications study: Navigating the road to 2020, viewed 21 June 2016, from http://www.ey.com/Publication/vwLUAssets/eyglobal-telecommunications-study-navigating-the-road-to-2020/\$FILE/ey-globaltelecommunications-study-navigating-the-road-to-2020.pdf

Fiorentino, A., 2014, 'Cost drivers-based method for machining and assembly cost estimations in mould manufacturing', International Journal of Advanced Manufacturing

Firli, A., Primiana, I. \& Kaltum, U., 2015, 'The impact of increasing CAPEX on customer number, profit, and ROI in Indonesia telecommunication industry', American Journal of Economics 5(2), 135-138.

Frisanco, T., 2010, 'Benchmark-based assessment of out-tasking, outsourcing, and managed services for mobile network operators', Network operations and management symposium, Osaka, Japan, April 19, viewed 23 July 2012, from

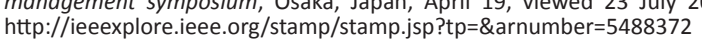

Geoffron, P., 2007, 'Infrastructure-based competition versus service-based competition in the European mobile market', in L. Benzoni \& P. Geoffron (eds.), A collection of essays on competition and regulation with asymmetries in mobile markets, pp. 37-42, Quantifica Publishing, Paris, viewed 11 October 2010, from http://www.teraconsultants.fr/assets/publications/PDF/2007-Juin-competition http://www.teraconsultants.fr/assets/publications/PDF/2007-Juin-competition andregulation-wi
Ed.pdf\#page $=43$

Golde, N., Redon, K. \& Seifert, J.P., 2013, 'Let me answer that for you: Exploiting broadcast information in cellular networks', Proceedings of the 22nd USENIX security symposium, Washington, DC, August 14-16.

GSMA, 2015, The mobile economy, viewed 21 June 2016, from http://www. gsmamobileeconomy.com/GSMA_Global_Mobile_Economy_Report_2015.pdf

Gujral, S., Dongre, K., Bhindare, S., Subramanian, P.G., Narayan, H.K.V., Mahajan, A. et al., 2010, 'Activity-based costing methodology as a tool for costing in hematopathology laboratory', Indian Journal of Pathology and Microbiology 53(1), 68-74. http://dx.doi.org/10.4103/0377-4929.59187

Gunasekara, S., 2015, 'Analysis and mathematical modelling of consumer behavior in mobile-telecommunications industry', International Journal of Scientific \& Technology Research 4(6), 333-343.

Harmantzis, F.C. \& Tanguturi, V.P., 2007, 'Investment decisions in the wireless industry applying real options', Telecommunications Policy 31, 107-123. http://dx.doi. org/10.1016/j.telpol.2006.02.005
Harmantzis, F.C., Trigeorgis, L. \& Tanguturi, V.P., 2006, Flexible investment decisions in the telecommunications industry: Case applications using real options, viewed 12 September 2011, from http://archive.nyu.edu/bitstream/2451/.../HarmantzisSeptember 2011, from
Trigeorgis_06-06.pdf.txt

H.R. Future, 2009, Skills needed to underpin telecom's growth, viewed 09 September 2012, from http://www.hrfuture.net/education-and-training/skills-needed-tounderpin-telecoms-growth. php?ltemid=265

International Telecommunication Union, 2012, Measuring the information society, viewed 10 April 2013, from http://www.itu.int/en/ITU-D/Statistics/Documents/ publications/mis2012/MIS2012_without_Annex_4.pdf

International Telecommunications Union, 2015, ICT facts and figures, viewed 21 June 2016, from https://www.itu.int/en/ITU-D/Statistics/Documents/facts/ICTFacts Figures2015.pdf

Jain, A., Rajput, A. \& Dixit, S., 2015, 'Evolution of wireless communication', International Journal of Engineering Technology Science and Research, 2(4), 88-90.

Jing, Z. \& Xiong-Jian, L., 2011, 'Business ecosystem strategies of mobile network operators in the 3rd era: The case of China Mobile', Telecommunications Policy 35 156-171. http://dx.doi.org/10.1016/j.telpol.2010.12.009

Katz, R.L. \& Hamilton, B.A., 2003, Remedies for telecom's recovery project, managerial strategy recommendations, Final report, Columbia Business School, viewed 20 June 2013, from http://www.citi.columbia.edu/CITI_Managerial_advisorycomm.pdf

Krug, B., Van Zanten, A., Pirson, A.S., Crott, R. \& Borght, T.V., 2009, 'Activity-based costing evaluation of a [18f]-fludeoxyglucose position emission tomography study', Health Policy 92(2/3), 234-243. http://dx.doi.org/10.1016/j.healthpol. 2009.04.002

Lange, P., 2012, South Africa: Telecoms, mobile, broadband and forecasts, Executive summary, The continent's leading telecoms and digital media market, viewed 13 April 2013, from http://www.buddeComm.mht

Lin, W.-C., 2012, 'Financial performance and customer service: An examination using activity-based costing of 38 international airlines', Journal of Air Transport Management 19, 13-15. http://dx.doi.org/10.1016/j.jairtraman.2011.12.002

Lincoln, Y.S. \& Guba, E., 1985, Naturalistic inquiry, Sage, Beverly Hill, CA.

Maher, M.W., Stickney, C.P. \& Weil, R.L., 2012, Managerial accounting, An introduction to concepts, methods and uses, 11th edn., South-Western, Mason, $\mathrm{OH}$.

McKinnon, J., 1988, 'Reliability and validity in field research: Some strategies and tactics', Accounting, Auditing and Accountability Journal 1(1), 34-54. http://dx. doi.org/10.1108/EUM0000000004619

Michalska, J. \& Szeweiczek, D., 2007, 'The improvement of the quality management by the activity-based costing', Journal of Achievements in Materials and Manufacturing Engineering 21(1), 91-94.

Miles, M.B. \& Huberman, M.A., 1994, An expanded sourcebook, Qualitative data analysis, 2 nd edn., Sage, Thousand Oaks, CA.

Miller, J.A., 1992, 'Designing and implementing a new cost-management system', Journal of Cost Management 6, 44-45.

Mishra, S.M., Hwang, J., Filippini, D. \& Moazzami, R., 2005, Economic analysis of networking technologies for rural developing regions, viewed 12 June 2013, from http://www.cs.nyu.edu/ lakshmi/wine.pdf

Moroney, S.D. \& Kual, A.R., 2003, Understanding healthcare cost drivers. National Institute of Health Policy, viewed 08 October 2012, from http://www. bluecrossmn. com/internet_core/es_ES/ccur/561/265/mbc1_healthcare_cost_drivers.pdf

Mowen, M.M., Hansen, D.R. \& Heitger, D.L., 2014, Cornerstones of managerial accounting, 5rd edn., South-Western, Mason, $\mathrm{OH}$.

Mpwanya, M.F. \& Van Heerden, C.H., 2015, 'Perceptions of managers regarding supply chain-cost reduction in the South African mobile-phone industry', Journal of Transport and Supply Chain Management 9(1), 1-11. http://dx.doi.org/10.4102/ jtscm.v9i1.176

MTN, 2014, MTN Group Limited. Integrated report, viewed 22 May 2016, from https://www.mtn.com/Sustainability/Documents/MTN_Group_Integrated_ Report_2014.pdf

Needles, B.E., Powers, M., \& Crosson, S.V., 2011, Accounting principles, 11th edn., International edition, South-Western, Mason, $\mathrm{OH}$.

Nieuwenhuis, J., 2007, 'Analysing qualitative data', in K. Maree (ed.), First steps in research, pp. 99-121, Van Schaik Publishers, Hatfield.

O’Dwyer, B., 2004, 'Qualitative data analysis: Illuminating a process for transforming a messy but attractive nuisance', in C. Humphrey \& B.H.K. Lee (eds.), The real-life guide to accounting research: A behind-the-scenes view of using qualitative research methods, pp. 391-407, Elsevier Limited, Oxford, UK.

Park, J. \& Simpson, T.W., 2008, 'Towards an activity-based costing system for product families and product platforms in the early stages of development', International Journal of Production Research 46(1), 99-130. http://dx.doi.org/10.1080/ 00207540600825240

Pattanavichai, S., Jongsawat, N. \& Premchaiswadi, W., 2011, 'Real options analysis for valuing strategic investments and decisions of the mobile virtualnetwork operator's investment in E-UMUTS', 9th international conference on ICT and knowledge engineering, Bangkok, Thailand, January 12-13, viewed 06 September 2012, from www.ieeexplore.ieee.org/stamp/stamp.jsp?tp=\&arnumber= 6152394

Popesko, B., 2010, 'Activity-based costing application methodology for manufacturing industries', E+M Ekonomika a Management 1:103-114.

PWC Analysis, 2012, We need to talk about Capex. Benchmarking best practice in telecom-capital allocation, viewed 12 December 2013, from https://www.pwc. com/gx/en/communications/publications/assets/pwc_capex_final_21may12.pdf 
Rachchh, M.A. \& Rachchh, G.A., 2015, Cost accounting, Methods and techniques (Financial Accounting and auditing Paper-IX), Vikas Publishing House (PVT) LTD, New Delhi.

Reeve, J.M., Warren, C.S. \& Duchac, J.E., 2009, Principles of managerial accounting, 10th edn., South-Western, Cengage Learning, Mason, $\mathrm{OH}$.

Research ICT Africa, 2012, Africa prepaid mobile price index 2012: South Africa viewed 17 April 2013, from http://www.researchictafrica.net/docs/SA_Mobile Prepaid_policy_brief.pdf

Rich, J.S., Jones, J.P., Heitger, D.L., Mowen, M.M. \& Hansen, D.R., 2010, Cornerstones of financial and managerial accounting, Current trends, International Edition, South-Western, Cengage Learning, Mason, $\mathrm{OH}$.

Richards, L., 2009, Handling qualitative data, A practical guide, 2nd edn., Sage Publications, London.

Sabat, H.K., 2002, 'The economics of delivering mobile wireless value', The Journal of Business Perspective 6, 53-72. http://dx.doi.org/10.1177/097226290200600206

Su, T.Y. \& Lei, X.H., 2008, 'Research on supply chain cost-reduction based on process and time analysis', Proceedings of the 2008 IEEE international conference on industrial engineering and engineering management, Singapore, December 8-11, viewed 13 June 2013, from http://ieeexplore.ieee.org/stamp/stamp.jsp?tp=\& arnumber $=4738147$
Telkom, 2015, Telkom integrated report, viewed 15 March 2016, from http://www. telkom.co.za/ir/apps_static/ir/pdf/financial/pdf/Telkom $\% 20$ IR $\% 202015 \% 20$ Final.PDF

Tsai, W.-H., Shen, Y.-S., Lee, P.-L., Chen, H.-C., Kuo, L. \& Huang, C.-C., 2012, 'Integrating information about the cost of carbon through activity-based costing', Journal of Cleaner Production 36, 102-111. http://dx.doi.org/10.1016/j.jclepro.2012.02.024

Van Eeden, J., 2009, 'The economics of mobile interconnection rates in South Africa' Econex Research Note 15, 4, viewed 14 May 2013, from http://www.econex.co.za/ index.php?option=com_docman\&task

Vincenti-Brown, C., 2006, 'Cost and the supply chain', in J.B. Ayers (ed.), Handbook of supply-chain management, 2nd edn., pp. 305-317, Auerbach Publications/ Taylor \& Francis Group, Boca Raton, FL.

Wang, P., Du, F., Lei, D. \& Lin, T.W., 2010, 'The choice of cost drivers in activity-based costing: Application at a Chinese oil well cementing company', Internationa Journal of Management 27(2), 367-380.

Wyman, O., 2007, Network outsourcing and sharing are changing the face of the mobile phone industry. Press release, viewed 13 April 2013, from http://www. oliverwyman.com/media/PR_analysis_network-models_dig.pdf

Yin, R.Y., 2009, Case study research: Design and methods, 4th edn., Sage Publications, Thousand Oaks, CA. 